\title{
Impact of inundation regime on wild bee assemblages and associated bee-flower networks
}

\author{
Ulrich NeUMÜlLER $^{1,2}$, Bärbel PACHINGER ${ }^{3}$, Konrad FIEDLER $^{1}$ \\ ${ }^{1}$ Division of Tropical Ecology and Animal Biodiversity, University of Vienna, Rennweg 14, 1030, Vienna, Austria
${ }^{2}$ Institute of Evolutionary Ecology and Conservation Genomics, University of Ulm, Albert-Einstein-Allee 11, 89081,
Ulm, Germany
${ }^{3}$ Institute for Integrative Nature Conservation Research, University of Natural Resources and Life Sciences Vienna \\ (BOKU), Gregor-Mendel-Straße 33, 1180, Vienna, Austria
}

Received 24 January 2018 - Revised 20 August 2018 - Accepted 6 September 2018

\begin{abstract}
Wild bee assemblages on flood-prone meadows were compared with those on rarely inundated sites along the river Danube in easternmost Lower Austria. We sampled flower-visiting bees on 32 meadows from April to August 2016. Although we recorded more bee individuals on rarely inundated meadows, total bee species richness was higher on regularly flooded meadows and we observed a stronger differentiation diversity of bees among annually flooded meadows. Three network metrics derived from a bipartite plant-bee interaction matrix were unaffected by flooding regime. We conclude that extreme floods, which sporadically affect the investigated habitats, may have a devastating effect on wild bee populations, but communities quickly recover. This resilience surely depends on recolonization from the surrounding landscape, which emphasizes the need to consider community dynamics in highly variable floodplain areas not only locally, but on a landscape scale.
\end{abstract}

\section{wild bees / community recovery / species richness / floodplain ecology / bipartite networks}

\section{INTRODUCTION}

A central paradigm of ecological theory is that disturbances shape the composition and dynamics of biological systems (Tilman 2004; Lepori and Malmqvist 2009). Transient population declines caused by floods have been described for wild bees (Fellendorf et al. 2004) and many other terrestrial insect groups (Gerisch et al. 2012; Fies et al. 2016). More precisely, Roubik (1992) stated that inundation of nest-cells and associated mold growth represents a major threat for the brood of soil-nesting

Electronic supplementary material The online version of this article (https://doi.org/10.1007/s13592-018-0604-0) contains supplementary material, which is available to authorized users.

Corresponding author: U. Neumüller, ulrich.neumueller@uni-ulm.de

Manuscript editor Alexandra Klein bees. In addition, he described specific architectural modifications like water resistant cell linings to prevent water from entering the nests and further pointed out that such safety measures can strongly vary between different bee taxa. Nevertheless, floodplain areas often house diverse bee communities (Loeffel et al. 1999, Archer 2001) and several studies suggest that regular flooding events result in distinct vegetation types and structural variation of habitats, which in turn leads to a high beta diversity of the inhabiting fauna (Loeffel et al. 1999; Van Looy et al. 2003). Under the premise that bee communities show sufficient resilience to flooding, river dynamics could therefore potentially even increase overall bee diversity in regions subject to a regular inundation regime (Loeffel et al. 1999). Truxa and Fiedler (2012) found a slightly richer moth fauna in floodplain forests than in neighboring non-flooded forest habitats and Gerisch et al. (2012) documented exceptionally strong resilience to flooding for ground beetles. The findings of Loeffel 
et al. (1999) who surveyed recolonization processes of wild bee assemblages suggest that wild bees may be similarly resilient to inundations.

While responses of bee assemblages to various environmental disturbances have been documented in multiple cases (Loeffel et al. 1999; Fellendorf et al. 2004; Holzschuh et al. 2007), much less is known about the biotic networks that result from interactions between flowers and bees. A bipartite network analysis can provide profound insights into the characteristics of a community and especially into the strength of inter-dependencies between species (Dormann et al. 2016).

The main objective of the present study was to explore to what extent flood events shape local bee communities and associated bee-flower networks, aiming at a deeper understanding about what role floodplain systems may play as habitat for wild bees. Such an understanding is clearly important in view of the prominent function of wild bees in pollinator networks (Biesmeijer et al. 2006) as well as the severe declines of many wild bee populations all over Central Europe (Potts et al. 2010).

\section{METHODS}

\subsection{Study area and data acquisition}

The study was carried out in the Donau-Auen National Park which represents the largest (9300 ha) functional riparian environment to remain in Central Europe (Fies et al. 2016). Here, the Danube almost yearly causes flooding events in late June or July, resulting in regular inundations of wide areas of the reserve (Blöschl et al. 2013). Since the building of a levee in the 1870 s, substantial parts of the park are no longer subject to the regular flooding regime (Klasz et al. 2013).

Half of the 32 surveyed meadows were situated on the flood-prone (southern) and another 16 on the protected (northern) side of the levee (Fig. 1). We chose sites in a way that they cover the range of different meadow types present in the national park. To reduce spatial autocorrelation, sampling plots were situated at least $200 \mathrm{~m}$ apart, of which a minimum of $50 \mathrm{~m}$ was dense woodland. The last extreme inundation of the Danube occurred in 2013, whereas during the following years, floods were particularly weak (Fig. 2). Since the summer flood in 2016 had only one, exceptionally short peak (DoRIS 2016), inundation did not disrupt the sampling effort at all.

Bee-flower networks on 32 meadows were recorded during four sampling periods between the end of April and the beginning of August. Each site was sampled for 30 min per survey, resulting in a total observation time of $120 \mathrm{~min}$ per site. Bee sampling was carried out on $30 \times 60 \mathrm{~m}$ plots in a central position on each meadow. Before sampling started, we identified potential nectar or pollen plants in flower. Then, every bee interacting with reproductive parts of a plant was collected with an insect net. Bees that we could not identify on the spot were captured for later species identification. We noted honeybee observations, but as they appeared only very sporadically, this data was not included into the statistical evaluation.

Sampling was only performed during sunny weather, on days without strong wind (< $10 \mathrm{~km} / \mathrm{h}$ ) and between $0930 \mathrm{~h}$ and $1600 \mathrm{~h}$. The plant species on which each bee had been collected was recorded, identified after Fischer et al. (2008), and assigned to its observed flower visitor. We also recorded if a meadow had been mown since the last survey had taken place.

\subsection{Network analyses}

We performed data analysis using $\mathrm{R}$ Studio (RStudio Team 2016), which is an integrated development environment (IDE) for $\mathrm{R}$ ( $\mathrm{R}$ Development Core Team 2015).

Network metrics and figures regarding the network analysis were generated using the $\mathrm{R}$ package "bipartite" (Dormann et al. 2016). The interaction webs of the 32 individual meadows were characterized by quantitative network parameters only, aggregating the four temporal replicates available per site. Since the datasets were rather small, the probability of a strong bias when using qualitative parameters appeared too high (Banašek-Richter et al. 2004; Power and Stout 2011).

We considered the following three network metrics: (I) H2': A network-level measure of specialization, describing to which extent observed interactions deviate from those that would be expected given the species marginal totals (Dormann et al. 2016). The more selective a 


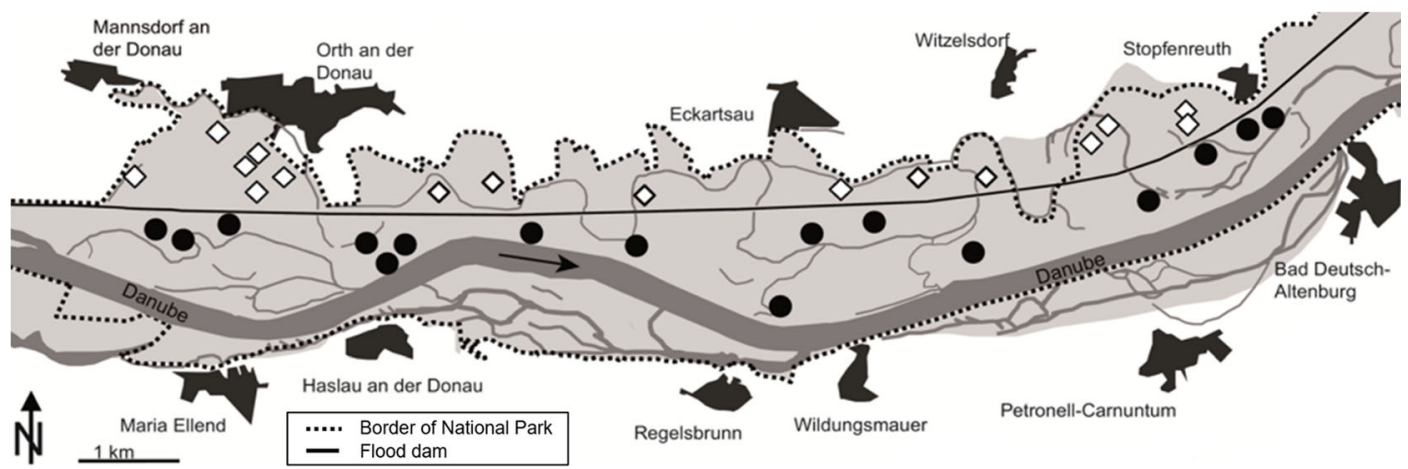

Figure 1. Map of the sampling area between Orth an der Donau and Stopfenreuth. Positions of the meadows are marked with dots (south of the levee) or diamonds (north of the levee). The map was provided by Fies et al. (2016) and modified.

species, the larger is $\mathrm{H} 2^{\prime}$ for the web. The resulting $\mathrm{H} 2$ ' values range between 0 (no specialization) and 1 (perfect specialization for given interaction totals) (Dormann et al. 2009). (II) Vulnerability: Weighted linkage for plants, calculated as the weighted mean number of insect visitor taxa per plant species (Tiedeken and Stout 2015). (III) Niche overlap for higher trophic level: Mean similarity in interaction pattern between flowervisiting species. Values near 0 indicate no common use of niches, while a value of 1 indicates perfect niche overlap (Dormann et al. 2009).

\subsection{Statistical analysis}

To compare species richness between bee assemblages on either side of the levee, we calculated randomized individual-based and sample site-based species accumulation curves using the package "iNEXT" (Chao et al. 2016). To achieve meaningful sample sizes for this analysis, we aggregated sites north and south of the levee, respectively, into one species-abundance list each.

To test if position of sites relative to the levee (two categories) and mowing status (if the meadow had been mown since the last sampling effort) had an effect on observed bee activity density and observed number of bee species per survey, two general linear mixed models (GLMMs) as implemented in the "Ime4" package (Bates et al. 2016) were performed. Here, we used data from the individual surveys separately and included the meadow-ID as random factor.

In another set of GLM analyses, we tested if the three network metrics (see above) were influenced by the position relative to the levee. In these

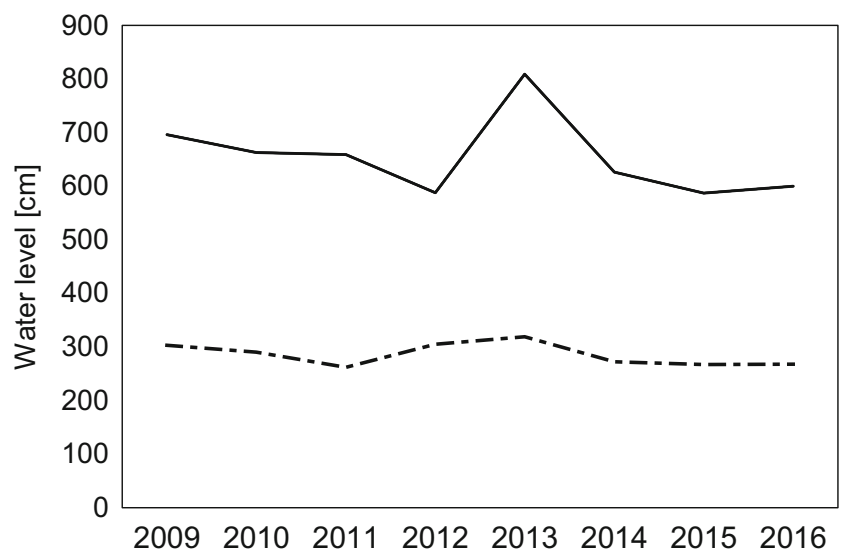

Figure 2. Maximum (solid line) and mean (dashed line) water levels of the Danube river at Korneuburg (Lower Austria) from the years 2009 to 2016. (Data from DoRIS 2016). 
models, we included the proportion of oligolectic bee individuals as predictor because the extent of specialization was expected to have a major effect on most network metrics (Dormann et al. 2016). Following Scheuchl and Willner (2016), we defined a bee species as oligolectic if it only forages for pollen on plant species in one family or genus. All network metrics except of vulnerability (which was log transformed) were logit transformed to improve fit to linear models with Gaussian error structure.

From the quantitative species lists of all 32 meadows, we calculated a Bray-Curtis matrix and subjected this to an analysis of similarities (ANOSIM, 1000 permutations), implemented in the package "VEGAN" (Oksanen et al. 2017), to test for effects of flooding on bee species composition.

To determine if the position of meadows relative to the dam affected the dispersion of bee assemblages with regard to their species composition, we performed a permutation-based multivariate analog of Levene's test for homogeneity of variances with $10^{4}$ permutations, as implemented in the package "VEGAN" (Oksanen et al. 2017).

\section{RESULTS}

During the survey, we recorded 710 wild beeflower interactions, including 92 wild bee species interacting with 61 flowering plant species. North of the levee, we registered 61 different wild bee species and 413 wild bee-flower interactions, south of the levee 71 wild bee species participated in 297 interactions. This is surprising, as the mean number of observed species per Meadow was even slightly, but not significantly lower on meadows situated south of the dam $(\overline{\mathrm{x}}=10, \mathrm{SD}=3.795)$ than north of the dam $(\overline{\mathrm{x}}=11, \mathrm{SD}=4.662)$.

Both, individual-based and sample site-based species accumulation curves paint a clear picture: wild bee species richness was higher on the floodprone meadows south of the levee (Fig. 3). More precisely, both approaches showed nonoverlapping confidence intervals, although for the sample site-based accumulation curves an extrapolation to the factor 1.75 was required.

GLMM analyses revealed a significantly higher activity density of wild bees on flood- protected meadows, but there was no relationship between the position of meadows north or south of the levee and the recorded species numbers per survey (Table I, Fig. 4). Actual mowing status of the meadows, in contrast, had a highly significant negative effect on both, species numbers and activity density (Fig. 4). Fortunately, mowing happened relatively equally on both meadow categories, with 13 mowing events (of which nine occurred before the third and four before the fourth sampling event) on flood-protected, and 11 mowing events (of which nine took place before the third and two before the fourth sampling event) on regularly inundated meadows.

Position of meadows relative to the levee showed no significant effect on any of the tested network metrics on the level of individual meadows. H2' showed a weak tendency towards a higher specialization of networks south of the dam. Both, niche overlap and network vulnerability were negatively related to the proportion of oligolectic bees in the networks (Table II, Fig. 5).

Species composition of wild bee assemblages differed weakly, but significantly between meadows of the two flood regimes (ANOSIM: $R=0.092, p=0.021)$. Moreover, species composition was significantly more heterogeneous $(\mathrm{df}=$ $1, F=7.556, p=0.011$ ) on the meadows south of the levee than on northern meadows.

\section{DISCUSSION}

Ninety-two wild bee species were found in total, which equals to $13.3 \%$ of the total wild bee fauna known from Lower Austria (Gusenleitner et al. 2012). The steep unsaturated species accumulation curves, especially for the southern meadows, indicate that there are many species left which we did not capture during the surveys. As expected, wild bee activity density was strongly influenced by the mowing status, which is closely connected to the actual availability of floral resources on a meadow, one of the top factors driving wild bee abundances (Potts et al. 2003; Holzschuh et al. 2007; Holzschuh et al. 2013, Buri et al. 2014). The extremely low activity density on all meadows, which had been mown since the last survey, was certainly the main reason for the strong negative correlation between mowing status and observed species richness. 
a

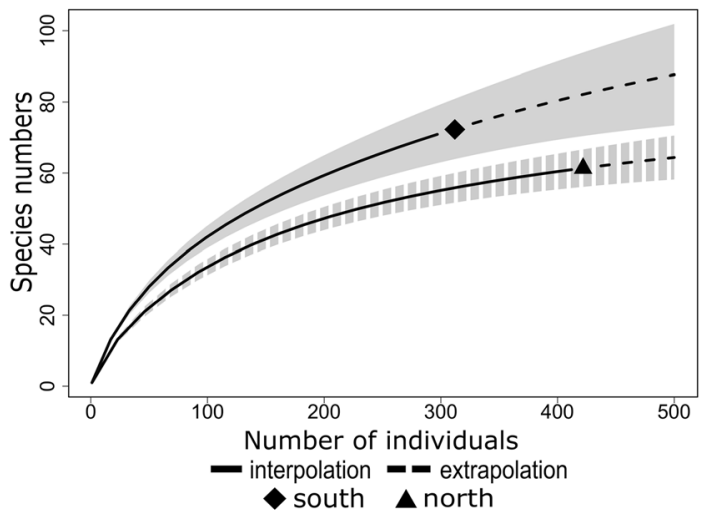

b

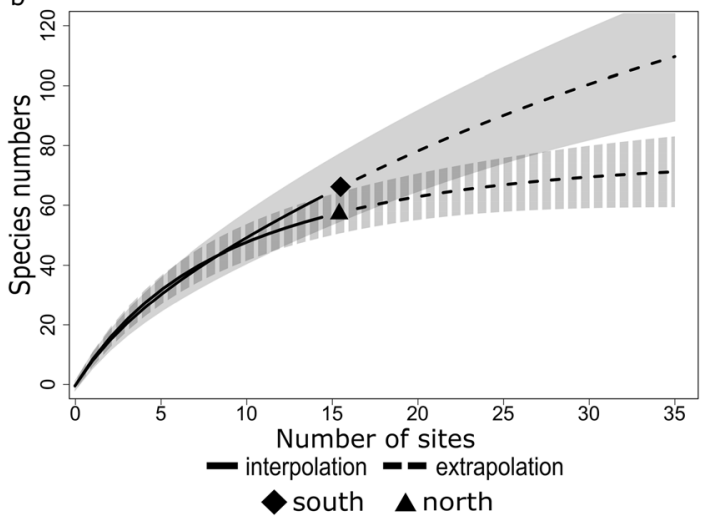

Figure 3. Individual-based (a) and sample site-based (b ) randomized species accumulation curves of wild bee species numbers observed on meadows north and south of the levee. The shaded areas represent $95 \%$ confidence intervals.

While actual species richness per survey did not differ between flood regimes, species accumulation curves indicated an overall higher species richness if aggregated over all southern, annually flood-prone meadows. Concordant with that, Truxa and Fiedler (2012) also found a slightly richer moth fauna in flooded than on nonflooded forest habitats in the same region. Gerisch et al. (2012) identified an exceptionally high beta diversity of ground beetles on meadows experiencing frequent inundations. We recorded more bee species south of the dam, although the mean number of observed species per meadow was actually marginally lower than north of the dam. Therefore, the larger species richness at the aggregated scale (north vs. south of the dam) cannot be ascribed to a generally higher richness on every single flood-prone meadow, but rather to the significantly higher bee species turnover in this part of the reserve. This increased turnover is likely driven by a higher habitat diversity in floodplain systems that experience near-annual disturbance of different intensity over time (Van Looy et al. 2003). Pollock et al. (1998) showed that extremely high spatial variation of flooddisturbance regimes in an area only as small as $1000 \mathrm{~m}^{2}$ was mainly caused by micro-topography, and this variable micro-topography then translated into increased floristic diversity (Vivian-Smith 1997). A similar variation likely exists for meadows south of the dam in the Donau-Auen National Park. Intensity and regularity of inundation events strongly influence successional processes and consequently the spatio-temporal heterogeneity of riverine floodplain plant communities (Hupp 1983; Ward et al. 1999; Van Looy et al. 2003). In a meta-analysis, Tews et al. (2004) found that in $85 \%$ of all 85 considered studies, a positive correlation existed between animal species diversity and habitat heterogeneity.

Consistent with the conclusion of higher differentiation diversity to prevail south of the dam, we observed more bee species on these meadows, even though we recorded significantly more bee

Table I.. Results of general linear mixed models testing the effects of position (North/South of the levee) and mowing status on wild bee activity density and species numbers. Significant effects $(p<0.05)$ printed in italic. Additionally, conditional and marginal $R^{2}$ values after Nakagawa and Schielzeth (2013) are given.

\begin{tabular}{llllrr}
\hline Dependent variables & Marginal $R^{2}$ & Conditional $R^{2}$ & Explanatory variables & $z$ & $p$ \\
\hline Wild bee activity density & 0.5829 & 0.5829 & Position & -2.422 & 0.015 \\
& & & Mowing status & -8.907 & $<0.001$ \\
Wild bee species number & 0.508 & 0.516 & Position & -1.178 & 0.239 \\
& & & Mowing status & -6.588 & $<0.001$ \\
\hline
\end{tabular}



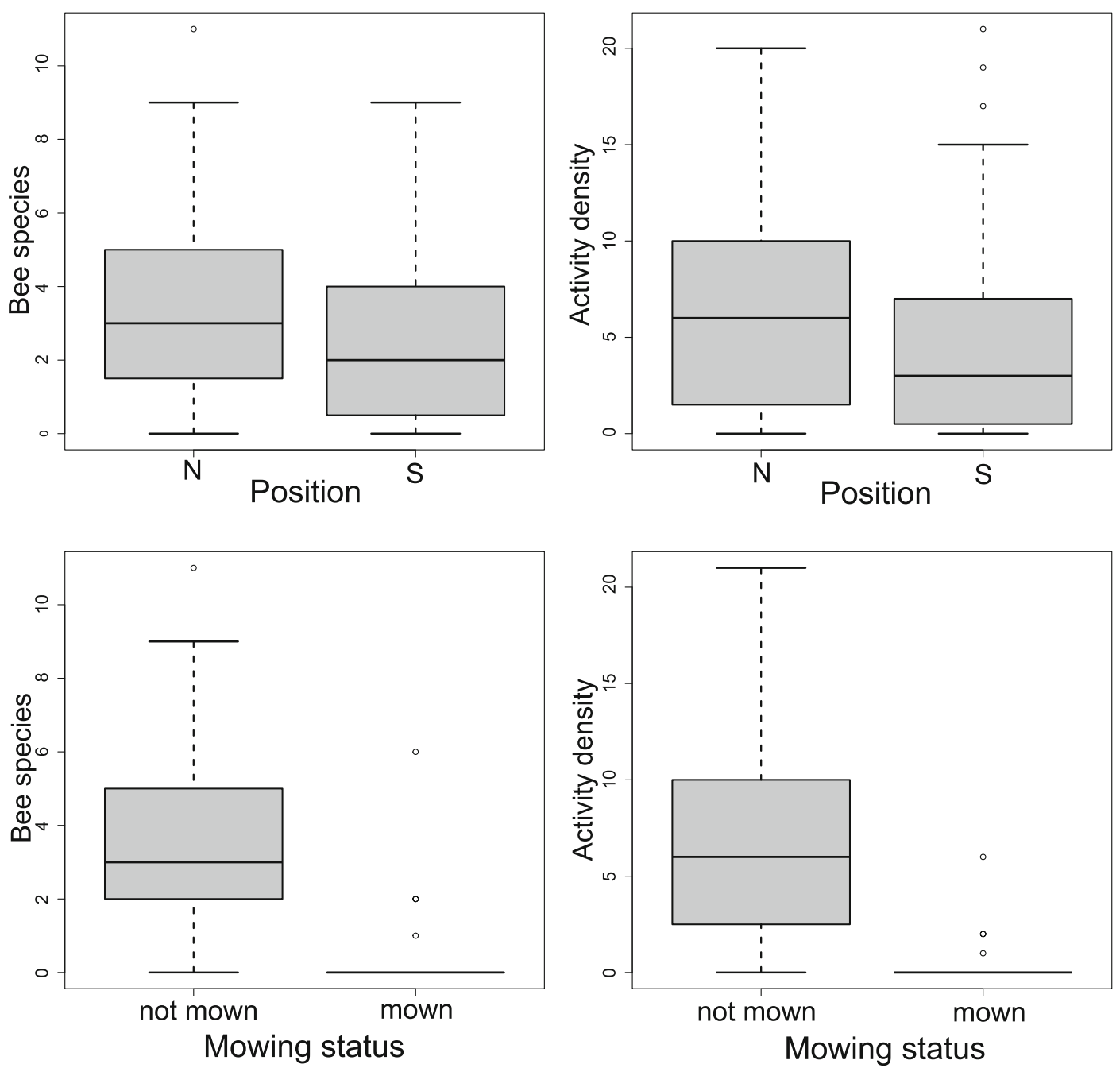

Figure 4. Effect of position relative to the levee (top) and mowing status (bottom) on number of observed wild bee species and activity density. Box-and-whisker-plot, range $=1.5 \times \mathrm{IQR} . \mathrm{N}$, North of the dam (flood-protected); $\mathrm{S}$, South of the dam (flood-prone).

individuals north of the dam. The significantly lower activity density south of the dam could be a sign that bee assemblages were still in an early state of succession after the severe flood in 2013 (Gerisch et al. 2012, Blöschl et al. 2013) and communities had not reached an equilibrium state again. For example, species numbers of ground beetles recovered within only 2 years, whereas abundances were barely restored 4 years after a severe flood event of the Elbe River (Gerisch et al. 2012).

Our data indicate a rather low long-term impact of flooding events on wild bee assemblages. Nevertheless, Fellendorf et al. (2004) observed a massive population decline of two aggregations of Andrena vaga after a strong inundation event. This suggests that at least some soil-nesting bees may show low resistance towards floods. Gerisch et al. (2012) concluded that ground beetles exhibit a very low resistance but high resilience to extreme flooding events and attributed this resilience to reproductive traits and high dispersal power of beetles. If we presume that wild bees have at least similar dispersal abilities as most ground beetles, it seems likely that they are equally resilient to flooding. Using butterflies as focal taxon, Fies et al. (2016) found exactly the same pattern: 
Table II.. Results of general linear models testing the effects of selected explanatory variables on three network parameters. Significant effects $(p<0.05)$ printed in italic. Additionally, mean $( \pm \mathrm{SE})$ network parameter values of all meadows together and pseudo- $R^{2}$ after Nagelkerke (1991) are given.

Quantitative network parameters

\begin{tabular}{llllll}
\hline Dependent variables & Mean $\pm \mathrm{SE}$ & $R^{2}$ & Explanatory variables & $t$ & $p$ \\
\hline Vulnerability & $2.57 \pm 0.25$ & 0.609 & Position & 0.330 & 0.743 \\
& & & Proportion oligolectic & -4.30 & $<0.001$ \\
H2' & $0.80 \pm 0.03$ & 0.161 & Position & 1.814 & 0.08 \\
& & & Proportion oligolectic & 1.761 & 0.089 \\
Niche overlap & $0.25 \pm 0.04$ & 0.224 & Position & 1.397 & 0.173 \\
& & & Proportion oligolectic & -2.057 & 0.048 \\
\hline
\end{tabular}

immediately after a very strong flood, butterfly numbers on inundated meadows collapsed, but within weeks, numbers of sightings per survey returned to pre-flooding levels. Altogether, it appears that terrestrial insect communities in central European riparian habitats show a low resistance to floods, but rapid recolonization allows for restoring their communities after a short while (Gerisch et al. 2012; Truxa and Fiedler 2012; Fies et al. 2016). The last extreme inundation of the Danube in 2013 occurred with a severity estimated to take place only once every 200 years (Land Niederösterreich 2017), whereas during the following years, floods were particularly weak (Fig. 2). Therefore, two consecutive years of but moderate flooding seemed to be enough time for substantial recovery of the bee community.

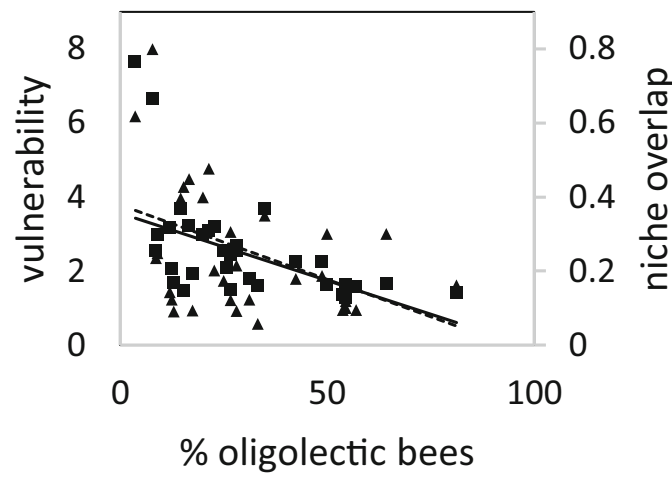

Figure 5. Scatter plot showing influence of the proportion of oligolectic bees on vulnerability (squares, dashed trend line, left Y-axis) and niche overlap (triangles, solid trend line, right $\mathrm{Y}$-axis) values for bipartite bee-flower networks.
In contrast to other invertebrate groups (Truxa and Fiedler 2012; Demetz et al. 2013; Fies et al. 2016), the effect of flooding on wild bee species composition was significant, but rather weak. A possible explanation for this pattern could be the pronounced dispersal abilities of wild bees, which can overcome wide distances of several hundred meters when searching for suitable nesting sites (Roubik 1992; Loeffel et al. 1999). The open landscape today prevailing in Central Europe is largely a result of human activity. The primary natural habitats of bees were often sand dunes and dynamic floodplains, which implies that most species are probably well adapted to such variable habitats or have evolved sufficient recolonization abilities (Archer 2001).

With regard to the regular disturbance regime south of the levee, one can assume a strong source to sink dynamics in the national park (Jones 2011; Leibold et al. 2004). Amarasekare and Nisbet (2001) showed that a dispersal-competition tradeoff may lead to local coexistence of superior and inferior competitors, provided that the inferior competitor is superior at colonizing empty patches as well as immigrating among occupied patches. Due to the high frequency of disturbance events south of the dam (Gerisch et al. 2012; Fies et al. 2016), these dynamics likely play a more prominent role concerning local community assembly processes on the flood-prone meadows.

Results of our network analyses further emphasize the high resilience of flower-bee interactions to flood regimes: None of the examined network metrics significantly differed between annually 
flood-prone and non-flooded meadows 2 years after the last strong flooding event had happened.

With a grand mean of 0.8 , the network specialization $\mathrm{H}^{\prime}$ ' of all meadows was rather high when compared with other studies (Popic et al. 2013; Carvalho et al. 2014; Zotarelli et al. 2014; Baldock et al. 2015) where values ranged between 0.4 and 0.6. This high value can either be an indication of extremely high specialization in the networks of this study or, more likely, of incomplete coverage of the networks. Fründ et al. (2015) stated that compilations of interaction data are prone to be incomplete even after intensive sampling. In addition, several meadows showed mass-occurrences of individual flowering plant species during one or two sampling periods which also led to a high apparent specialization, or rather concentration, since most bees then fed on the same highly abundant plant (e.g., Symphytum officinale, Solidago gigantea, or Salvia pratensis). Mean network vulnerability was only slightly lower than in former studies (Popic et al. 2013). The mean niche overlap value integrated over all meadows was $25 \%$. This value corresponds with the high grade of apparent specialization in the networks.

As expected, niche overlap and vulnerability were significantly lower in networks with a higher proportion of oligolectic bees. This indicates that resource partitioning plays an important role in shaping alimentary preferences among coexisting bee species (Ranta and Lundberg, 1980; Johnson, 1986; Blüthgen and Klein, 2011).

Although meadows in the regularly flooded part of the national park housed a more speciesrich bee community, they seem to be constantly threatened by local extinction through severe flooding events. Fortunately, after such disturbances, recolonization seems to happen rather fast, and a diverse bee community is restored by assembly from the regional meta-community after only a few years. To ensure such rapid recolonization, it is most important that there are source areas from where bee species can re-distribute after flooding events. We therefore emphasize the particular importance of the wider (nonflooded) surrounding landscape which certainly plays a crucial role in sustaining local bee diversity south of the dam. Finally, since mowing almost completely eliminates the food sources of bees on meadows at a short term, it is surely advisable to establish an unsynchronized mowing regime or even spare parts of meadows from frequent management to provide a refuge for wild bees and other flower-feeding invertebrates (Cizek et al. 2012; Buri et al. 2014).

\section{AUTHORS' CONTRIBUTION}

Ulrich Neumüller conceived the survey design, performed field sampling, and undertook the taxonomic and statistical data evaluation. Konrad Fiedler participated in developing the survey design and statistical data evaluation and contributed to writing of the manuscript. Bärbel Pachinger contributed to the identification of taxonomically challenging bee specimens and to the final manuscript version.Funding information

We thank the University of Vienna and the Donau-Auen National Park for providing financial support for the realization this study.

\section{COMPLIANCE WITH ETHICAL STANDARDS}

Conflict of interest The authors declare that they have no conflict of interest.

Impact du régime d'inondation sur les assemblages d'abeilles sauvages et les réseaux abeilles-fleurs associés

Abeilles sauvages / rétablissement communautaire / richesse spécifique / écologie des plaines inondables / réseaux bipartites

Der Einfluss von Überschwemmungsereignissen auf die Ansammlungen von Wildbienen und assozierte BienenBlüten-Netzwerke

Wildbienen / Wiederherstellung von Gemeinschaften / Artenreichtum / Ökologie von Überschwemmungs landschaften / bipartite Netzwerke

\section{REFERENCES}

Amarasekare, P., Nisbet, R. M. (2001) Spatial heterogeneity, source-sink dynamics, and the local coexistence of competing species. Am. Nat. 158 (6), 572-584 
Archer, M. E. (2001) The wasps and bees (Hymenoptera: Aculeata) of the river bank at Beningbrough and Keswick Fitts in Watsonian Yorkshire. Ent.s Gaz, 52, 105-115

Baldock, K. C., Goddard, M. A., Hicks, D. M., Kunin, W. E., Mitschunas, N., et al. (2015) Where is the UK's pollinator biodiversity? The importance of urban areas for flowervisiting insects. Proc. R. Soc. London B. 282 (1803), 1-10

Banašek-Richter, C., Cattin, M. F., Bersier, L. F. (2004) Sampling effects and the robustness of quantitative and qualitative food-web descriptors. J. Theor. Biol. 226 (1), 23-32

Bates, D., Maechler, M., Bolker, B., Walker, S., Christensen, R. H. B., Singmann, H., Dai, B., Grothendieck, G., Green, P. (2016) Linear Mixed-Effects Models using 'Eigen' and S4. Version 1.1-12 [online] https://cran.r-project.org/web/packages/lme4 /lme4.pdf (accessed on 10 January 2018)

Biesmeijer, J. C., Roberts, S. P., Reemer, M., Ohlemüller, R., Edwards, M., et al. (2006) Parallel declines in pollinators and insect-pollinated plants in Britain and the Netherlands. Science 313 (5785), 351-354

Blüthgen, N., Klein, A. M. (2011) Functional complementarity and specialisation: the role of biodiversity in plantpollinator interactions. Basic Appl. Ecol. 12 (4), 282-291

Blöschl, G., Nester, T., Komma, J., Parajka, J., Perdigão, R. A. P. (2013) The June 2013 flood in the Upper Danube Basin, and comparisons with the 2002, 1954 and 1899 floods. Hydrol. Earth Syst. Sci. 17 (12), 5197-5212

Buri, P., Humbert, J. Y., Arlettaz, R. (2014) Promoting pollinating insects in intensive agricultural matrices: field-scale experimental manipulation of hay-meadow mowing regimes and its effects on bees. PLoS One 9(1), e85635

Carvalho, D. M., Presley, S. J., Santos, G. M. M. (2014) Niche overlap and network specialization of flowervisiting bees in an agricultural system. Neotrop. Entomol. 43 (6), 489-499

Chao, A., Ma, K. H., Hsieh, T. C. (2016) Interpolation and Extrapolation for Species Diversity version 2.0.12 [online] https://cran.r-project.org/web/packages/ iNEXT/iNEXT.pdf (accessed on 10 January 2017)

Cizek, O., Zamecnik, J., Tropek, R., Kocarek, P., Konvicka, M. (2012) Diversification of mowing regime increases arthropods diversity in species-poor cultural hay meadows. J. Insect Conserv. 16(2), 215-226

Demetz, A., Fiedler, K., Dreschke, T. Schulze, C.H. (2013) Natural floodplain dynamics shape grasshopper assemblages of meadows in the Donau-Auen National Park (Austria). Symposium for Research in Protected Areas (Austria) 5 : 125-129

DoRIS (2016) Jahresverlauf [online] http://www.doris. bmvit.gv.at/fahrwasserinformation/pegelstaende/ jahresverlauf/ (accessed on 10 January 2017)

Dormann, C. F., Fründ, J., Blüthgen, N., Gruber, B. (2009) Indices, graphs and null models: analyzing bipartite ecological networks. Open Ecol. J. 2, 7-24

Dormann, C. F., Fründ, J., Gruber, B. (2016) Package 'bipartite'. Visualising Bipartite Networks and Calculating Some (Ecological) Indices version 2.07 [online] https:/cran.r-project.org/web/packages/bipartite/bipartite.pdf (accessed on 10 January 2017)
Fellendorf, M., Mohra, C., Paxton, R. J. (2004) Devasting effects of river flooding to the ground-nesting bee, Andrena vaga (Hymenoptera: Andrenidae), and its associated fauna. J. Insect Conserv. 8(4), 311-312

Fies, R., Rabl, D., Schulze, C. H., Fiedler, K. (2016) Summer floods shape meadow butterfly communities in a floodplain nature reserve in Central Europe. J. Insect Conserv. 20 (3), 433-445

Fischer, M. A., Oswald, K., Adler, W., Gottschlich, G., Englmaier, P., et al. (2008) Exkursionsflora für Österreich, Liechtenstein und Südtirol. OÖ. Landesmuseen, Linz

Fründ, J., McCann, K. S., Williams, N. M. (2015) Sampling bias is a challenge for quantifying specialization and network structure: lessons from a quantitative niche model. Oikos 125, 502-13

Gerisch, M., Dziock, F., Schanowski, A., Ilg, C., Henle, K. (2012) Community resilience following extreme disturbances: The response of ground beetles to a severe summer flood in a Central European lowland stream. River Res. Appl. 28(1), 81-92

Gusenleitner, F., Schwarz, M., Mazzucco, K. (2012) Checkliste der Fauna Österreichs, No. 6. Biosystematics and Ecology-Series No. 29. Verlag der Österreichischen Akademie der Wissenschaften, Vienna, pp. 1-129

Holzschuh, A., Steffan-Dewenter, I., Kleijn, D., Tscharntke, T. (2007) Diversity of flower-visiting bees in cereal fields: effects of farming system, landscape composition and regional context. J. Appl. Ecol 44 (1), 41-49

Holzschuh, A., Dormann, C. F., Tscharntke, T., SteffanDewenter, I. (2013) Mass-flowering crops enhance wild bee abundance. Oecologia 172 (2), 477-484

Hupp, C. R. (1983) Vegetation pattern on channel features in the Passage Creek Gorge, Virginia. Castanea 62-72

Jones, J. P. (2011) Monitoring species abundance and distribution at the landscape scale. J. Appl. Ecol. 48(1), 9-13

Johnson, R. A. (1986) Intraspecific resource partitioning in the bumble bees Bombus ternarius and $B$. pennsylvanicus . Ecology 67 (1), 133-138

Klasz, G., Reckendorfer, W., Baumgartner, C., Gabriel, H., Gutknecht, D. (2013) River-bed degradation and overbank deposition: A human induced geomorphic disequilibrium in the Donau-Auen National Park. Symposium for Research in Protected Areas (Austria) 5, 379-384

Land Niederösterreich (2017) Wasserstandsnachrichten, Hochwasserprognosen in Niederösterreich [online] http://www.noel.gv.at/Externeseiten/wasserstand/ static/stations/207241/station.html (accessed on 10 January 2017)

Leibold, M. A., Holyoak, M., Mouquet, N., Amarasekare, P., Chase, J. M., et al. (2004) The metacommunity concept: a framework for multi-scale community ecology. Ecol. Lett. 7 (7), 601-613

Lepori, F., Malmqvist, B. (2009) Deterministic control on community assembly peaks at intermediate levels of disturbance. Oikos 118(3), 471-479

Loeffel K., Streich S., Westrich P., Zettel J. (1999) Auensukzession und Zonation im Rottensand (Pfynwald, 
Kt. VS). II. Wiederbesiedlung einer Überschwemmungsfläche durch Wildbienen (Hymenoptera, Apidae). Mitt. schweiz. ent. Ges. 71, 139-151

Nagelkerke, N. J. (1991) A note on a general definition of the coefficient of determination. Biometrika, 78 (3), 691-692

Nakagawa, S., Schielzeth, H. (2013) A general and simple method for obtaining R2 from generalized linear mixedeffects models. Methods Ecol. Evol. 4(2), 133-142

Oksanen, J., Blanchet, F. G., Friendly, M., Kindt, R., Legendre, P., et al. (2017) The vegan package. Community ecology package. Version 2.4-2 [online] https:/cran.r-project.org/web/packages/vegan/vegan. pdf (accessed on 10 January 2018)

Pollock, M. M., Naiman, R. J., Hanley, T. A. (1998) Plant species richness in riparian wetlands - a test of biodiversity theory. Ecology 79 (1), 94-105

Popic, T. J., Wardle, G. M., Davila, Y. C. (2013) Flowervisitor networks only partially predict the function of pollen transport by bees. Austral Ecol. 38(1), 76-86

Potts, S. G., Vulliamy, B., Dafni, A., Ne'eman, G., Willmer, P. (2003) Linking bees and flowers: how do floral communities structure pollinator communities? Ecology 84 (10), 2628-2642

Potts, S. G., Biesmeijer, J. C., Kremen, C., Neumann, P., Schweiger, O., Kunin, W. E. (2010) Global pollinator declines: trends, impacts and drivers. Trends Ecol. Evol. 25 (6), 345-353

Power, E., Stout, J. C. (2011) Organic dairy farming: impacts on insect flower interaction networks and pollination. J. Appl. Ecol. 48, 561-569

R Development Core Team (2015) R: A language and environment for statistical computing, http://www.R-project. org. R Foundation for Statistical Computing, Vienna

Ranta, E., Lundberg, H. (1980) Resource partitioning in bumblebees: the significance of differences in proboscis length. Oikos 35(3), 298-302

Roubik, D. W. (1992) Ecology and natural history of tropical bees. Cambridge University Press., Cambridge, pp. 194-195
RStudio Team (2016) R Studio: Integrated Development for R. https://www.rstudio.com/products/rstudio/. RStudio Inc., Boston

Scheuchl, E., Willner, W. (2016) Taschenlexikon der Wildbienen Mitteleuropas. Quelle \& Meyer Verlag, Wiebelsheim, pp. 545-547

Tews, J., Brose, U., Grimm, V., Tielbörger, K., Wichmann, M. C., Schwager, M., Jeltsch, F. (2004) Animal species diversity driven by habitat heterogeneity/diversity: the importance of keystone structures. J. Biogeogr. 31 (1), 79-92

Tiedeken, E. J., Stout, J. C. (2015) Insect-flower interaction network structure is resilient to a temporary pulse of floral resources from invasive Rhododendron ponticum. PLoS One 10 (3), 0119733

Tilman, D. (2004) Niche tradeoffs, neutrality, and community structure: a stochastic theory of resource competition, invasion, and community assembly. Proc. Natl. Acad. Sci. U.S.A. 101 (30), 10,854-10,861

Truxa, C., Fiedler, K. (2012) Down in the flood? How moth communities are shaped in temperate floodplain forests. Insect Conserv. Divers. 5 (5), 389-397

Van Looy, K., Honnay, O., Bossuyt, B., Hermy, M. (2003) The effects of river embankment and forest fragmentation on the plant species richness and composition of floodplain forests in the Meuse valley, Belgium. Belg. J. Bot. 136 (2), 97-108

Vivian-Smith, G. (1997) Microtopographic heterogeneity and floristic diversity in experimental wetland communities. J. Ecol. 85 (1), 71-82

Ward, J. V., Tockner, K., Schiemer, F. (1999) Biodiversity of floodplain river ecosystems: ecotones and connectivity. Regulated Rivers: Research \& Management, 15 (1), 125-139

Zotarelli, H. G. S., Evans, D. M., Bego, L. R., Sofia, S. H. (2014) A comparison of social bee-plant networks between two urban areas. Neotrop. Entomol. 43 (5), 399-408 